Sains Malaysiana 50(4)(2021): 989-996

http://doi.org/10.17576/jsm-2021-5004-09

\title{
Colorimetric Amine Detection by Vanillin-Hydrazone Derivatives during Chicken Meat Spoilage
}

(Pengesanan Amina Colorimetrik oleh Terbitan Vanilin-Hidrozon semasa Kerosakan Daging Ayam)

Bambang Purwono*, Beta Achromi Nurohmah \& Suharman

\section{ABSTRACT}

Two vanillin-hydrazone compounds as the colorimetric amine detection during chicken meat spoilage are described. Two hydrazone compounds (1 and 2) have been synthesized from the condensation reaction of vanillin with phenylhydrazine and 2,4-dinitrophenylhydrazine. Their properties for colorimetric recognition of amine were determined by the naked eye and $U V$-vis spectra. Their properties as amine indicators were investigated toward primary amine: butylamine (BA); secondary amine: dimethylamine (DMA), diethylamine (DEA); tertiary amine: triethylamine (TEA), and also ammonia (Amm). The hydrazone 1 in DMSO showed no significant color changes (colorless) after the addition of amines solution. Hydrazone $2\left(5 \times 10^{-5} \mathrm{M}\right.$ in DMSO) showed color changes from yellow to violet in the presence of ammonia, DEA and $B A$, to reddish-violet for DMA, and light brown after addition of TEA solutions. The colorimetric amine detection by vanillin-hydrazone 2 could recognize the real amine during chicken meat spoilage from yellow to light brown after 24 h storage at room temperature.

Keywords: Colorimetric; food spoilage; hydrazone; indicator

\section{ABSTRAK}

Dua sebatian vanilin-hidrazon sebagai pengesanan am kolorimetrik semasa kerosakan daging ayam dijelaskan. Dua sebatian hidrazon (1 dan 2) telah disintesis daripada tindak balas pemeluwapan vanilin dengan fenilhidrazin dan 2,4-dinitrofenilhidrina. Sifat mereka untuk pengecaman amina kolorimetrik ditentukan oleh mata kasar dan spektrum UVvis. Sifat mereka sebagai petunjuk amina dikaji terhadap amina primer: butilamina (BA); amina sekunder: dimetilamina (DMA), dietilamina (DEA); amina tertier: trietilamina (TEA) dan juga amonia (Amm). Hidrazon 1 dalam DMSO tidak menunjukkan perubahan warna yang ketara (tidak berwarna) setelah penambahan larutan amina. Hidrazon $2(5 \times 10-5$ M dalam DMSO) menunjukkan perubahan warna daripada kuning ke ungu dengan adanya amonia, DEA dan BA, menjadi ungu kemerahan untuk DMA dan coklat muda setelah penambahan larutan TEA. Pengesanan amina kolorimetrik oleh vanilin-hidrazon 2 dapat mengenali amina sebenar semasa kerosakan daging ayam daripada kuning ke coklat muda setelah penyimpanan 24 jam pada suhu bilik.

Kata kunci: Hidrazon; kerosakan makanan; kolorimetrik; penunjuk

\section{INTRODUCTION}

A safety measurement in the consumption of food is essential because it is related to human health. The freshness indicators of food can be seen from the appearance, texture, color, and odor changes. Food spoilage on meat and fish-based food commonly occur due to the production of biogenic amines that formed from microorganism activity. Biogenic amines are a low molecular weight of organic bases generated from decarboxylation of amino acids. The formation of biogenic amines can initiate an allergic reaction in humans, characterized by itching, rash in skin, vomiting, fever, hypertension, and hard in breathing (Naila et al. 2010).

Total volatile base-nitrogen (TVB-N) is described as a combination of the total amount of ammonia (Amm), dimethylamine (DMA), and trimethylamine (TMA). A high-level amount of biogenic amines and TVB-N can increase as a consequence of microbial contamination or unhygienic circumstances during the manufacturing and processing, as well as an inappropriate handling and storage condition (Bóka et al. 2012). 
Biogenic amines serve as a potential chemical indicator of poor quality of meat and fish-based products along with TVB-N and TMA. Analytical methods have been developed for detecting to TVB-N and biogenic amines. The amines level in food are analyzed by thinlayer chromatography (TLC), enzymatic, high-performance liquid chromatography (HPLC), gas chromatography (GC), flow injection analysis (FIA), colorimetric, and fluorometric methods (Arulkumar et al. 2017; Ruiz-Capillas \& Herrero 2019). The identification of meat spoilage is also developed through polymerase chain reactions (PCR), spectroscopy, and odor sensor device (Fletcher et al. 2018). Polymerase chain reactions (PCR) are used to detect the presence of some bacteria that can spoil meat samples such as Salmonella strains (Rodriguez-Lazaro et al. 2014), Brochothrix species (Gribble \& Brightwell 2013), Clostridium species (Brightwell \& Clemens 2012; Reid et al. 2017). An electronic nose (e-nose) as the gas sensor monitored the freshness of chicken meat by employing metal oxide sensor (MOS) system and comparing the result with other methods (Raudiene et al. 2018).

Among the various detection methods, an optical sensor is the most convenient technique of all (Chen et al. 2010). These methods offer a simple, rapid, and also cost-effective method for detection of BAs, TVB-N, and TMA. The design of a colorimetric sensor is fundamentally based on supramolecular chemistry, which depends on the interaction between the molecules such as the formation of hydrogen-bonding, acid-base interaction, dipole-dipole, and van der Waals interaction (Janzen et al. 2006).

The lone electron pair of nitrogen in amine molecules could favor the nitrogen as a nucleophile or base. Moreover, it could highly bind with hydrogen ion to make a quaternary ammonium ion. Most of the aliphatic amines can form hydrogen bonds. In addition, amine sensor mechanisms also involve acid-base equilibrium between amines and sensor compound. Sensor sensitivity can be improved by increasing of acid-base interaction. Amines such as ammonia is weak base. It can be detected by acidic sensor. Acid properties of sensor compounds can be increased by inserting of electron withdrawing group substituent in the sensor compound structure (Duong \& Rhee 2014). Based on those mechanisms, an optical sensor for amines could be developed. Moreover, amine sensor compounds have been developed and used as a sensor for spoiled food indicators (Basavaraja et al. 2020).

In this work, we studied vanillin-hydrazone derivatives (1 and $\mathbf{2}$ ) as potential of amine sensors for food spoilage indicators in chicken meat. Compounds $\mathbf{1}$ and $\mathbf{2}$ were prepared through a condensation reaction of vanillin with phenylhydrazine and 2,4-dinitrophenyl hydrazine, respectively (Figure 1). Their properties as amine indicators were investigated toward primary amine: butylamine (BA); secondary amine: dimethylamine (DMA), diethylamine (DEA); tertiary amine: triethylamine (TEA), and also ammonia (Amm). Furthermore, their potential as a food spoilage indicator was performed to breast chicken meat after storage for 24 and $48 \mathrm{~h}$ at room temperature conditions.

\section{MATERIALS AND METHODS}

The chemicals used in this study were vanillin, phenylhydrazine, 2,4-dinitrophenyl hydrazine, glacial acetic acid $(\mathrm{AcOH})$, ethanol, ethanol, butylamine, diethylamine, dimethylamine $(40 \%)$, triethylamine, and ammonia (32\%). As for spectroscopic studies, dimethyl sulfoxide (DMSO) was used as a solvent. All reagents and solvents used were of analytical grade and purchased from E.Merck without further purification.

\section{INSTRUMENTATION}

Structural elucidation of the prepared compound was performed with Spectrophotometer FT-IR (Shimadzu Prestige-21), Spectrophotometer ${ }^{1} \mathrm{H}$ - and ${ }^{13} \mathrm{C}-\mathrm{NMR}$ (Liquid State-500 MHz/125 MHz), and GC-MS (Shimadzu QP-2010S). Melting points were measured using Electrothermal-9100 in open capillary tubes without any correction. UV-visible absorption spectra were recorded with Spectrophotometer UV-Vis (Shimadzu UV-1800 Eng. $240 \mathrm{~V}$ ) at room temperature (path length $1 \mathrm{~cm}$ ).

\section{SYNTHESIS OF HYDRAZONE 1 AND 2}

Synthesis of hydrazone $\mathbf{1}$ and $\mathbf{2}$ was conducted according to the previously reported method (Li et al. 2010). Vanillin $(0.31 \mathrm{~g} ; 2 \mathrm{mmol})$ was dissolved with $50 \mathrm{~mL}$ of ethanol in a base-round three-neck flask with a cooler condenser. The $2 \mathrm{mmol}$ of hydrazine (phenylhydrazine or 2,4-dinitrophenylhydrazine) was added along with 8-10 drops of glacial acetic acid to produce compound $\mathbf{1}$ and $\mathbf{2}$, respectively. The mixture was stirred and refluxed for 2-4 h. After the completion of the reaction, the mixture was poured into crushed ice, and the precipitate formed was filtered, washed with distilled water, and dried for further analysis.

\section{SYNTHESIS OF 2-METHOXY-4-PHENYLHYDRAZONE PHENOL (1)}

Brownish white solid, m.p.: $95.6-96.8^{\circ} \mathrm{C}$, yield $70.25 \%$. FTIR (KBr) cm ${ }^{-1}: 3487(\mathrm{O}-\mathrm{H}) ; 3317(\mathrm{~N}-\mathrm{H}) ; 3047$ (Csp²-H), 2924 and $2854\left(\mathrm{Csp}^{3}-\mathrm{H}\right) ; 1597(\mathrm{C}=\mathrm{N}) ; 1157$ and $2337(\mathrm{C}-$ $\mathrm{N}) ; 1273$ (C-O-C). ${ }^{1} \mathrm{H}-\mathrm{NMR}\left(500 \mathrm{MHz}\right.$; acetone- $\left.d_{6}\right)$ : $\delta / \mathrm{ppm}$ $9.23(\mathrm{OH}, \mathrm{s}, 1 \mathrm{H}) ; 7.80(\mathrm{CH}=\mathrm{N}, \mathrm{d}, J=2.6 \mathrm{~Hz}, 1 \mathrm{H}) ; 7.39$ 
(aromatic, d, $J=1.95 \mathrm{~Hz}, 1 \mathrm{H}$ ); 7.20 (aromatic, m, 2H); 7.16 (aromatic, m, 1H); 7.04 (aromatic, dd, $J=1.95$ and $8.45 \mathrm{~Hz}, 1 \mathrm{H}$ ); 6.83 (aromatic, d, $J=8.40 \mathrm{~Hz}, 1 \mathrm{H}$ ); 3.91 $\left(-\mathrm{OCH}_{3}, \mathrm{~s}, 3 \mathrm{H}\right) .{ }^{13} \mathrm{C}-\mathrm{NMR}\left(125 \mathrm{MHz}\right.$; acetone- $\left.d_{6}\right): \delta / \mathrm{ppm}$ $153.7 ; 149.1 ; 132.2 ; 130.3 ; 130.1 ; 127.1 ; 123.5 ; 122.4$; $116.0 ; 112.5 ; 110.9 ; 56.3$. GC-MS (m/z): $242\left(\mathrm{M}^{+}\right)$.

\section{SYNTHESIS OF 4-((2-(2,4-DINITROPHENYL) HYDRAZONE) METHYL)-2-METHOXYPHENOL (2)}

Red solid, m.p.: $268.8-270.2{ }^{\circ} \mathrm{C}$, yield $79 \%$. IR cm${ }^{-1}$ : 3394 (O-H); 3278 (N-H); 3109 (Csp $\left.{ }^{2}-\mathrm{H}\right), 2924$ and 2854 $\left(\mathrm{Csp}^{3}-\mathrm{H}\right) ; 1612(\mathrm{C}=\mathrm{N}) ; 1512$ and $1334\left(\mathrm{NO}_{2}\right) ; 1419$ $\left(\mathrm{CH}_{3}\right) ; 1273(\mathrm{C}-\mathrm{N}) ; 1134$ and 1087 (C-O-C). ${ }^{1} \mathrm{H}-\mathrm{NMR}$ (DMSO- $\left.d_{6}\right): \delta / p p m ~ 11.58(\mathrm{OH}, \mathrm{s}, 1 \mathrm{H}) ; 9.71(\mathrm{NH}, \mathrm{s}, 1 \mathrm{H})$; 8.86 (aromatic, d, $J=2.6 \mathrm{~Hz}, 1 \mathrm{H}) ; 8.58(\mathrm{CH}=\mathrm{N}, \mathrm{s}, 1 \mathrm{H})$; 8.35 (aromatic, dd, $J=2.6$ and $9.7 \mathrm{~Hz}, 1 \mathrm{H}$ ); 8.09 (aromatic, $\mathrm{d}, J=9.7 \mathrm{~Hz}$ ), 1H); 7.39 (aromatic, d, $J=1.3,1 \mathrm{H}) ; 7.17$ (aromatic, dd, $J=1.95$ and $8.7 \mathrm{~Hz}, 1 \mathrm{H}$ ); 6.87 (aromatic, $\mathrm{d}, J=8.5 \mathrm{~Hz}, 1 \mathrm{H}) ; 3.86\left(-\mathrm{OCH}_{3}, \mathrm{~s}, 3 \mathrm{H}\right) .{ }^{13} \mathrm{C}-\mathrm{NMR}(125$ MHz, DMSO- $\left.d_{6}\right): \delta /$ ppm $150.2 ; 149.6 ; 148.1 ; 144.4$; $136.5 ; 129.7 ; 128.9 ; 125.1 ; 123.1 ; 122.6 ; 116.7 ; 115.6$; $109.6 ; 55.6$.

\section{SPECTROSCOPIC STUDIES}

The spectroscopic studies of $\mathbf{1}$ and $\mathbf{2}$ were carried out in a concentration of $5 \times 10^{-5} \mathrm{M}$ from the stock solution $\left(1 \times 10^{-3} \mathrm{M}\right)$ in DMSO. The UV-Vis titrations were recorded from $2 \mathrm{~mL}$ of both 1 and 2 after addition of $50 \mu \mathrm{L}$ amines solution. Amines solutions were prepared in distilled water at various concentration (ranges from $1 \times 10^{-5}$ to $1 \mathrm{M}$ ). Amine solutions were prepared from ammonia (Amm) and butylamine (BA) as the primary amine, diethylamine (DEA), and dimethylamine (DMA) as the secondary amine, and triethylamine (TEA) for a tertiary amine.

Limit of detection (LOD) as determined by measuring the absorbance at the maximum wavelength after the addition of amine at different concentrations (range from $1 \times 10^{-5}$ to $4 \times 10^{-2} \mathrm{M}$ ). LOD was calculated with a formula of $3 \sigma^{-1}$, where $\sigma$ represents the standard deviation (SD) of the blank measurements and $m$ is the slope from the plot of the absorbance ratio versus concentration of the sample (Boruah et al. 2019). In this work, the SD was calculated from 10 times the measurement of the absorption of 2 without amine.

Job's plot was studied to determine the binding stoichiometry of $\mathbf{2}$ toward butylamine (BA) by plotting the mole fraction of $2([2] /[2]+[\mathrm{BA}])$ versus Absorbance at $490 \mathrm{~nm}\left(\mathrm{~A}_{490 \mathrm{~nm}}\right)$ with the total concentration of $[2]+[\mathrm{BA}]$ was maintained constant at $2 \times 10^{-4} \mathrm{M}$. Association constant $\left(\mathrm{K}_{\mathrm{a}}\right)$ of $\mathbf{2}$ was determined from the absorbance in titration plot $1 /\left(\mathrm{A}-\mathrm{A}_{0}\right)$ as a function of $1 /\left[\right.$ Amine] in $\mathrm{M}^{-1}$ according to the Benesi-Hildebrand plot. $\mathrm{A}$ and $\mathrm{A}_{0}$ are described as the absorbance of $\mathbf{2}$ after and before the addition of amine.

\section{PREPARATION OF PAPER-BASED COLORIMETRIC STRIP} TEST

The paper-based indicator test was prepared, according to Gao et al. (2016) with some modifications. The filter paper (Whatman 42) with diameter of $2 \mathrm{~cm}$ was immersed in a $1 \mathrm{~mL}$ solution of $2\left(\mathrm{DMSO} ; 1 \times 10^{-3} \mathrm{M}\right)$ for $15 \mathrm{~min}$ and then dried in an oven for overnight at $55^{\circ} \mathrm{C}$.

\section{PAPER-BASED COLORIMETRIC STRIP TEST FOR AMINES COMPOUNDS}

Colorimetric strip test was conducted by adding one drop of amine solutions (BA, DEA, and TEA without dilution) into paper-loaded hydrazone 2 . The colour response was observed and recorded.

\section{AMINE DETECTION ON REAL SAMPLE CHICKEN MEAT}

The real sample of boneless chicken breast was purchased from local market without special treatment. The sample was only sliced into small pieces and stored at chilled condition until it was ready to use. The vials used in this study have been sterilized using ethanol and dried in an oven. The vial was divided into three categories (A, B, and $C$ ) with $5 \mathrm{~g}$ of chicken meat sample in each vial. Vial A was used to detect the amine by immersing the sample with hydrazone solution and vial B was prepared to make an extract of chicken meat in water (water extract). Meanwhile, vial $\mathrm{C}$ was prepared to detect amine using a colorimetric paper-based strip. The samples were observed at three different storage time courses, i.e. 0,24 , and $48 \mathrm{~h}$ at room temperature.

The hydrazone $2\left(5 \times 10^{-5} \mathrm{M}, 3 \mathrm{~mL}\right)$ was added into vial A until all of the samples immersed in the solution. The sample was stirred for a while, let it stand for $15 \mathrm{~min}$ at room temperature, and filtered to obtain a clear filtrate. The colour changes were observed, and the UV-Vis spectra were also recorded using UV-Vis spectrophotometer.

Extract of chicken meat in water was prepared by adding $10 \mathrm{~mL}$ of water into vial $\mathrm{B}$ and stirred for a while before allowed to stand for $15 \mathrm{~min}$ at room temperature. The sample was then filtered to get the extracts and to remove the matrix. The amount of $75 \mu \mathrm{L}$ of this extract was added into $3 \mathrm{~mL}$ of hydrazone $2\left(5 \times 10^{-5} \mathrm{M}\right)$. The color response was observed, and the UV-Vis spectra were recorded using a UV-Vis spectrophotometer.

The paper-based colorimetric was tested into the chicken meat sample in two ways. Firstly, the chicken meat extract from a sample in vial B $(0.1 \mathrm{~mL})$ was dropped into 
the paper strip, and secondly, the strip test was inserted into vial $\mathrm{C}$ to detect amine in the gas phase. The colour responses from the test were then observed and recorded.

\section{RESULTS AND DISCUSSION}

\section{SYNTHESIS OF HYDRAZONE 1 AND 2}

The synthesis of hydrazone $\mathbf{1}$ and $\mathbf{2}$ was conducted through Schiff base-imine condensation reaction between vanillin and amine derivatives (phenyl hydrazine and 2,4-dinitrophenyl hydrazine) in the presence of glacial acetic acid as catalyst (Figure 1). The chemical structure of the prepared compounds $\mathbf{1}$ and $\mathbf{2}$ were confirmed by spectroscopic analysis.

\section{SPECTROSCOPIC SENSORY STUDIES}

The color responses of hydrazone $\mathbf{1}$ and $\mathbf{2}$ were observed in a preliminary experiment in the presence of 1000 moles equivalent (eq.) (1 M) amines solution. Figure 2(A) shows there were no significant color changes of $\mathbf{1}$ upon addition of amines. Therefore, UV-Vis spectra of $\mathbf{1}$ approved that no maximum wavelength $\left(\lambda_{\max }\right)$ was shifted to the visible area. The presence of amine (DEA and DMA) only shifted the $\lambda_{\text {max }}$ from 352 to $360 \mathrm{~nm}$ indicating interaction between 1 with amines via hydrogen bonding formation. Thus, the hydrazone 1 was almost colorless. This result showed the low color responses of $\mathbf{1}$ to the amines.

The preliminary studies of hydrazone 2 showed noticeable color changes upon the addition of 1000 moles equivalent (eq.) amines solution (1 M). Figure 2(B) shows the color of the solution changes from yellow to reddishviolet (with slightly different intensity) upon addition of butylamines (BA), dimethylamine (DMA), diethylamine (DEA) and ammonia (Amm). Meanwhile, the solution to reddish-brown after the addition of triethylamine (TEA).

The UV-Vis spectra of $\mathbf{2}$ showed the redshift from $415 \mathrm{~nm}$ (yellow) to $478-490 \mathrm{~nm}$ (red-violet) indicating hydrogen bonding formation followed by deprotonation of hydrogen at hydroxyl group. Primary amine (butylamine) gave the highest intensity of red/violet color compared with the secondary and tertiary amines. From the result, it also showed that tertiary amine gave the lowest response as seen in the comparison of the absorbance intensity at the $\lambda_{\text {max }}$ (Figure 2(B)). This study showed that introducing the nitro group into the hydrazone could increase acidity of compound 2. Therefore, sensing scheme involves acidbase equilibrium between amines and the HO-hydrazone (2) (1).

$\mathrm{RNH}_{2}+$ HO-hydrazone $(2) \longleftrightarrow \mathrm{RNH}_{3}^{+}+$ O-hydrazone (2)
As a result, hydrazone $\mathbf{2}$ has the ability and sensitivity to detect amine through colorimetric responses with the naked eye.

Ratiometric responses of hydrazone 2 as the concentration of amines gradually increasing was studied toward primary, secondary, and tertiary amines. The colour responses over the addition of butylamine as a primary amine were presented in Figure 3(A). It was noticed a colour changes from yellow to reddish-brown after addition $50 \mu \mathrm{L}$ of $2 \times 10^{-3} \mathrm{M}$ butyl amine solution. The colour intensity turns into a red and reddish violet as the concentration of BA was increasing gradually.

The presence of butylamine solution could make a redshift of the UV-Visible absorbance spectra, as shown in Figure 3(A). The maximum wavelength $\left(\lambda_{\max }\right)$ was shifted from 415 to $479-490 \mathrm{~nm}$, accompanied by the increase of the absorbance intensity. According to the spectra (Figure 3(B)), limit of detection (LOD) of hydrazone 2 to butylamine was $3.676 \times 10^{-6} \mathrm{M}(3.676 \mu \mathrm{M})$.

Similar response was observed in the presence of diethylamine (DEA) solution. The colour of the solution turns reddish-brown and gradually to be reddish violet after addition of DEA in various concentrations (Figure 4(A)). The UV-Vis spectra showed a redshift in the presence of diethylamine solution. The maximum wavelength $\left(\lambda_{\max }\right)$ was shifted from 415 to $477-490 \mathrm{~nm}$, accompanied by the colour changes from yellow to redviolet. As the $\lambda_{\text {max }}$ was shifted to the visible wavelength area, it was also noticed the increase of the absorbance intensity as the DEA concentrations were increasing. However, these responses were slightly lower than those to butylamine. The spectra also displayed the LOD of hydrazone 2 to diethylamine was $5.451 \times 10^{-6} \mathrm{M}(5.451$ $\mu \mathrm{M}$ ) (Figure 4(B)).

The lower colour change responses were observed after the addition of triethylamine (TEA) solution. The addition of $50 \mu \mathrm{L}$ TEA $\left(2 \times 10^{-3} \mathrm{M}\right)$ only resulted in the colour change from yellow to light brown, and as the concentration of TEA increase, it turns into reddishbrown (Figure 5(A)). These responses were significantly lower than those to butylamine and diethylamine. Tertiary amine should be the lower bases and due to its steric hindrance the three alkyl groups, it makes difficult the nitrogen to bond with protons of hydroxyl group from the hydrazone 2 . Thus, the interaction of TEA as a tertiary amine with the active site of hydrazone $\mathbf{2}$ was weaker than primary and secondary amines.

The UV-Visible spectra of hydrazone $\mathbf{2}$ in the presence of TEA solution were presented in Figure 5(A). Unlike the presence of BA and DEA, the addition of 50 $\mu \mathrm{L}$ TEA $2 \times 10^{-3} \mathrm{M}$ did not cause the disappearing of $\lambda_{\max }$ at $415 \mathrm{~nm}$. The addition of $2 \times 10^{-3} \mathrm{M}$ of TEA only caused 
$\lambda_{\max }$ at $415 \mathrm{~nm}$ slightly shifted to $416 \mathrm{~nm}$, thus, making the insignificantly colour changes. The new $\lambda_{\max }$ peak at $453 \mathrm{~nm}$ and more was observed after the addition of 50 $\mu \mathrm{L}$ TEA $5 \times 10^{-2} \mathrm{M}$ or higher concentration. That result showed that the sensitivity of hydrazone 2 toward TEA was significantly lower than sensitivity to BA and DEA. The calculated LOD of hydrazone 2 toward TEA (Figure 5B) was showed to be $5.985 \times 10^{-5} \mathrm{M}(59.85 \mu \mathrm{M})$.

The Job's plot of hydrazone 2 in Figure 6(A) confirmed 1:1 stoichiometric complexation with the butylamine. The absorbance of the sensor changes more rapidly from 0.5 to 1 eq. as the concentration of amine increased that indicates 1:1 complexation of hydrazone 2 with analytes (amine) (Erande et al. 2015).

Benesi-Hildebrand plot was drawn using UV-Vis titration data, and it depicted a plot of 1/[Amine] versus $1 /\left(\mathrm{A}-\mathrm{A}_{0}\right)$ at $490 \mathrm{~nm}$ (for BA and DEA) and $480 \mathrm{~nm}$ (for TEA) (Figure 6(B)). The linear expression of the BenesiHildebrand confirmed a 1:1 stoichiometric interaction of 2 with BA, DEA, and TEA. Binding constant from 1:1 complexation can be determined from the BenesiHildebrand plot with an equation of $\mathrm{c} / \mathrm{m}$ ( $c$ is intercept and $m$ is slope). The binding constant of hydrazone 2 with BA, DEA, and TEA were $3.15 \times 10^{2} ; 1.62 \times 10^{2} ; 5.3264 \times 10^{1}$ $\mathrm{M}^{-1}$ respectively. The binding constant proved that the chromogenic effect of BA was larger than DEA and TEA. The order of the binding constant was consistent with the sensitivity of amine to hydrazone 2 .

\section{PAPER-BASED COLORIMETRIC STRIP TEST}

One drop amine solution (without dilution) was used to study the color changes of the paper-loaded 2 . The colour response was seen turn to reddish-purple after BA and the DEA solution was dropped to the paper test (Figure 7(C)). Meanwhile, the paper test became dark yellow after the addition of the TEA solution, meaning the lower response of hydrazone 2 to TEA in form of paper test.

\section{AMINE DETECTION ON REAL SAMPLE CHICKEN MEAT}

The studies of hydrazone 2 solutions $\left(5 \times 10^{-5} \mathrm{M}\right.$ in DMSO $)$ for amine detection in breast chicken meat was conducted at different storage time at room temperature, i.e. 0,24 , and $48 \mathrm{~h}$. At first, $3 \mathrm{~mL}$ of hydrazone $2\left(5 \times 10^{-5} \mathrm{M}\right.$ in DMSO $)$ was used to soak the meat sample for $15 \mathrm{~min}$ at room temperature. The solution was then filtered to obtain a clear extract and the UV-vis spectra were measured afterward. It can be seen there were no colour changes of hydrazone 2 after used to immerse the meat sample (Figure 7(A)). This result was supported by the UV-vis spectra in Figure 7(A) that shows no spectral changes.

An extract of chicken meat sample in water $(75$ $\mu \mathrm{L}$ ) from different storage time was added into $3 \mathrm{~mL}$ solution of hydrazone 2 . The result shows there were no significant colour changes for sample at $0 \mathrm{~h}$ storage time, as seen in Figure 7(B). The colour response was observed from yellow to light brown for sample after 24 and 48 $\mathrm{h}$, respectively. The UV-vis spectra in Figure 7(B) also confirmed a bathochromic shift to the visible wavelength (from 415 to $420 \mathrm{~nm}$ ), accompanied by the decreasing absorbance intensity at $415 \mathrm{~nm}$. This result indicated that solution of hydrazone $\mathbf{2}$ could detect amines produced by spoiled chicken meat after $24 \mathrm{~h}$ storage.

The potential of a colorimetric paper-based test of $\mathbf{2}$ for amine detection of breast chicken meat spoilage was carried out toward amine water extract and volatile amine. The addition of $0.1 \mathrm{~mL}$ sample water extract from vial $\mathrm{B}$ into the hydrazone paper strip gave insignificant colour changes (Figure 7(D)). Moreover, when paper strip was put into a closed plastic box containing breast chicken meat and stored at $27-30{ }^{\circ} \mathrm{C}$ (room temperature), there were also no significant colour indicator paper changes after placing paper test in the container for $15 \mathrm{~min}$, even when meat was stored for two days the colour of paper test only turn to slightly reddish (Figure 7(E)). This result demonstrated that hydrazone 2, as a loaded filter paper indicator, has low sensitivity for detection of amines generated in chicken meat spoilage at lower concentration.

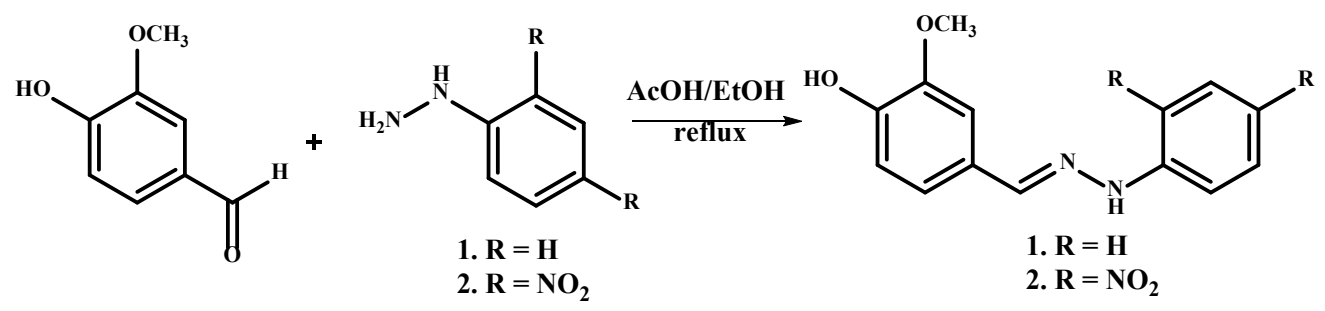

FIGURE 1. Reaction scheme of the synthesized hydrazone product (1 and $\mathbf{2}$ ) 

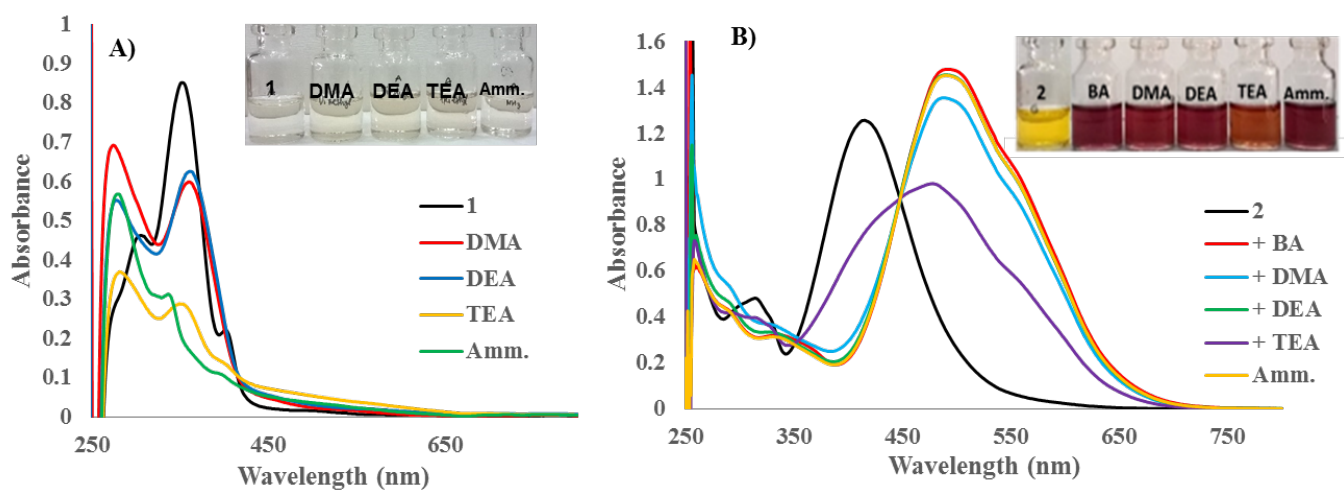

FIGURE 2. UV-Vis spectra and color changes of sensor $\mathbf{1}(\mathbf{A})$ and $\mathbf{2}(\mathbf{B})$ in DMSO $\left(5 \times 10^{-5} \mathrm{M}\right)$ over addition of 1000 moles equivalent $(50 \mu \mathrm{L} / 0.1 \mathrm{M})$ amine solution
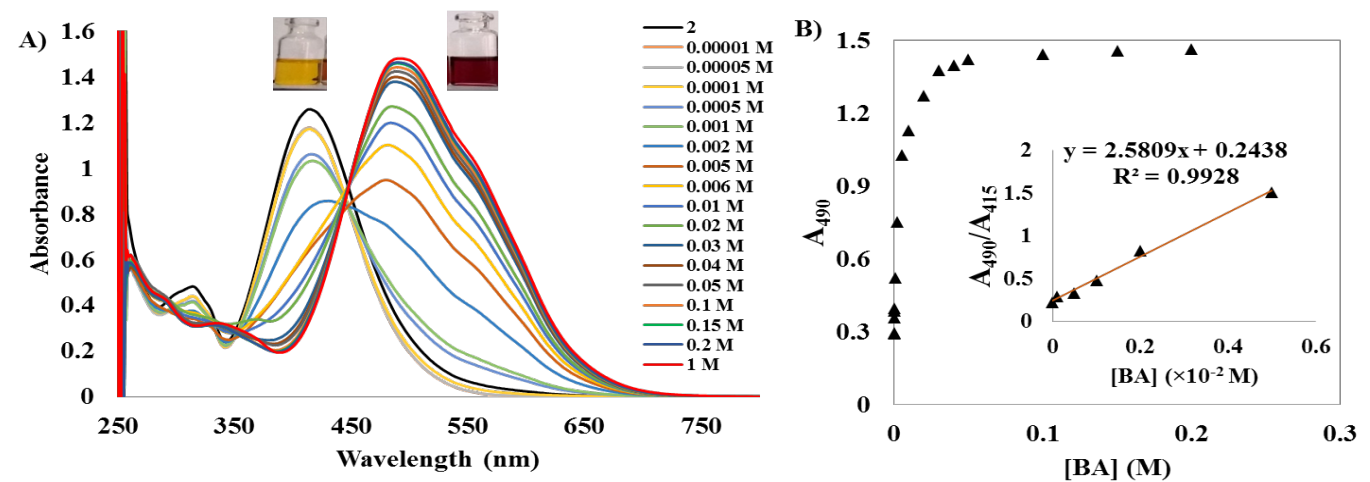

FIGURE 3. A) The colour changes and the UV-vis spectra of hydrazone 2 in DMSO $\left(5 \times 10^{-5} \mathrm{M}\right)$ over addition of $50 \mu \mathrm{L}$ of butylamine solution at various concentration; B) Absorbance of $\mathbf{2}$ as a function of concentration of butylamine at $490 \mathrm{~nm}$. Inset: Linier curve of the concentration of butylamine and absorbance ratio at 490/415 nm
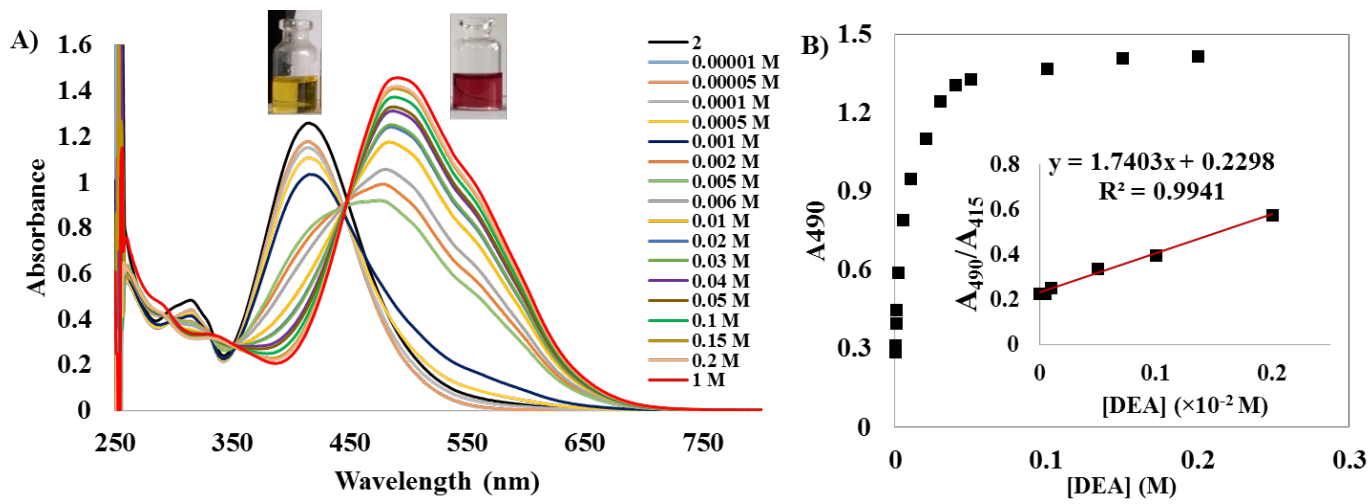

FIGURE 4. A) The colour changes and the UV-vis spectra of hydrazone 2 in DMSO $\left(5 \times 10^{-5} \mathrm{M}\right)$ over addition of $50 \mu \mathrm{L}$ of diethylamine solution at various concentration; B) Absorbance of $\mathbf{2}$ as a function of concentration of diethylamine at $490 \mathrm{~nm}$. Inset: Linier curve of the concentration of diethylamine and absorbance ratio at 490/415 nm 

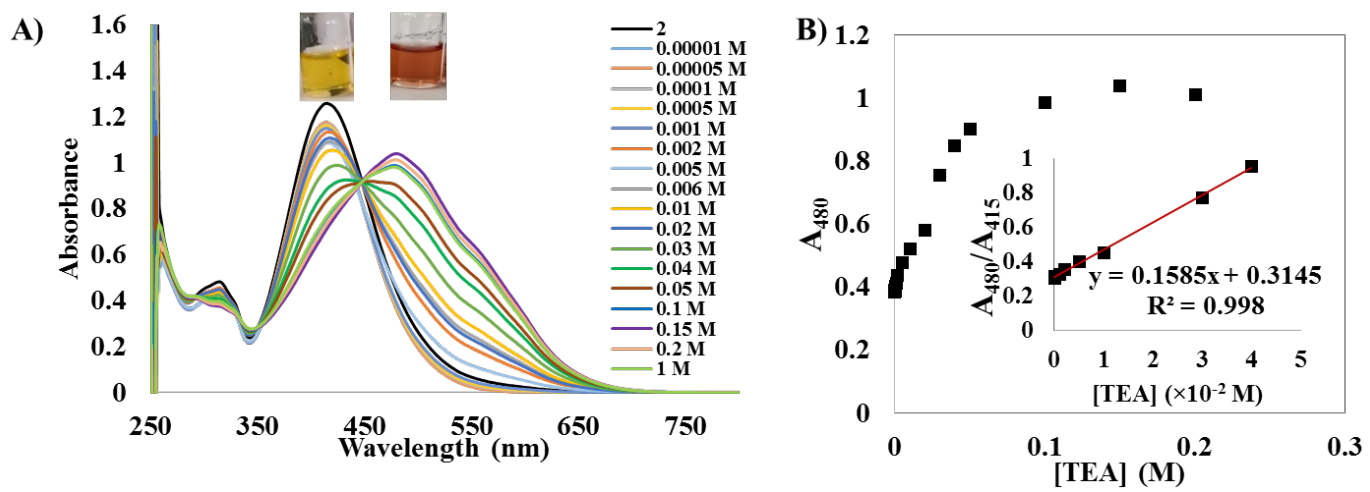

FIGURE 5. A) The colour changes and the UV-vis spectra of hydrazone 2 in DMSO $\left(5 \times 10^{-5}\right.$ M) over addition of $50 \mu \mathrm{L}$ of triethylamine solution at various concentration; B) Absorbance of $\mathbf{2}$ as a function of concentration of triethylamine at $480 \mathrm{~nm}$. Inset: Linier curve of the concentration of triethylamine and absorbance ratio at $480 / 415 \mathrm{~nm}$
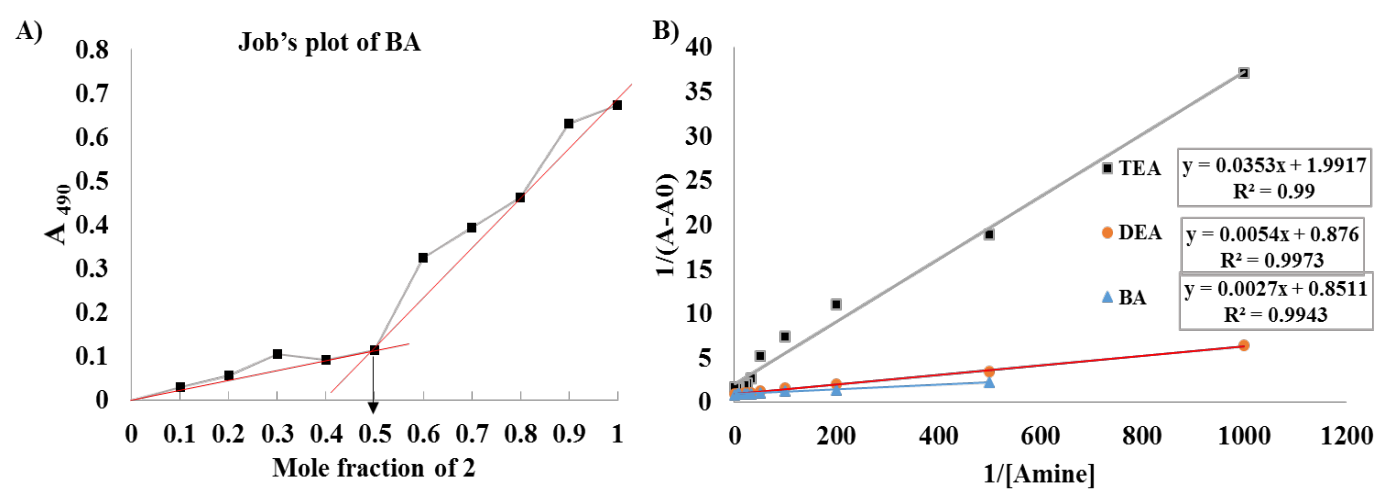

FIGURE 6. A) Job's plot of compound $\mathbf{2}$ in various mole fraction of butylamine (BA);

B) Benesi-Hildebrand plot based on UV-Vis titration of 2 (in DMSO) after addition of

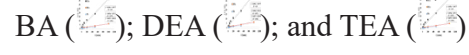

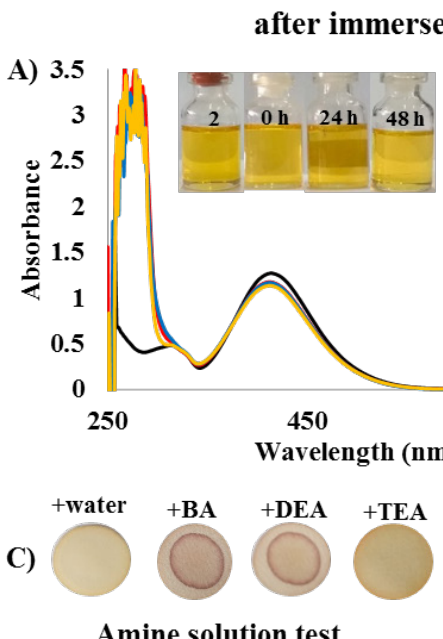

Amine solution test

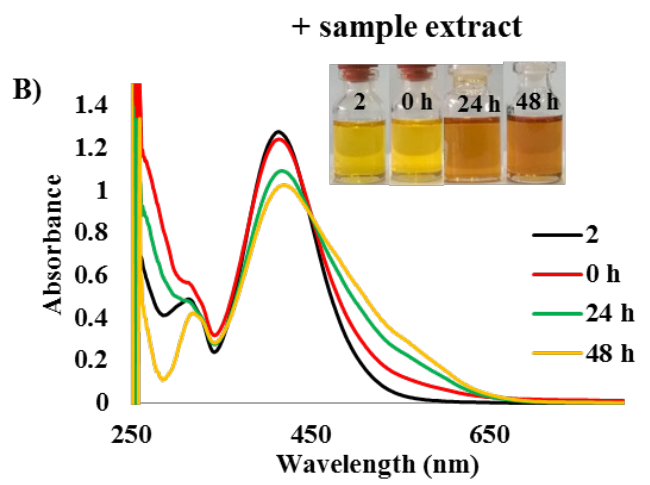

D)

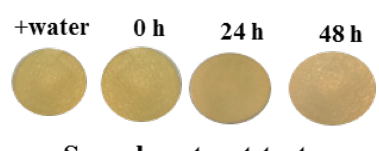

Sample extract test
E)

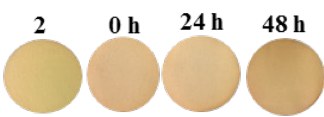

Sample vapor test

FIGURE 7. A) The color responses and the UV-Vis spectra of hydrazone 2 in DMSO $\left(5 \times 10^{-5} \mathrm{M}\right)$ after used to soak the meat sample; B) The color responses and the UV-Vis spectra of hydrazone 2 in DMSO $\left(5 \times 10^{-5} \mathrm{M}\right)$ in the presence of the water extract of chicken sample; $\left.\mathrm{C}\right)$ Color changes of strip test hydrazone 2 after addition of amine solutions (without dilution); D) Color changes of strip test hydrazone 2 after addition of $0.1 \mathrm{~mL}$ chicken breast water extract; E) Color changes of strip test hydrazone 2 after exposure to amine vapors 


\section{CONCLUSION}

In conclusion, we have investigated the hydrazone-vanillin compound $\mathbf{1}$ and $\mathbf{2}$ as a potential of colorimetric amine detection during chicken meat spoilage. The sensitivity for amines detection can be increased by inserting nitro group substituent to hydrazone 2 .

\section{ACKNOWLEDGEMENTS}

This work was funded by Grant of PUPT (Penelitian Unggulan Perguruan Tinggi), Universitas Gadjah Mada, with contract number of 2436/UN1.P.III/DIT-LIT/LT/2017.

\section{REFERENCES}

Arulkumar, A., Karthik, G., Paramasivam, S. \& Rabie, M.A. 2017. Histamine levels in Indian fish via enzymatic, TLC and HPLC methods during storage. Journal of Food Measurement and Characterization 11(1): 281-289.

Basavaraja, D., Dibyendu, D., Varsha, T.L., Chettiyan, T.F., Manas, K.P. \& Sasidhar, B.S. 2020. Rapid visual detection of amines by pyrylium salts for food spoilage taggant. $A C S$ Applied Bio Materials 3: 772-778.

Bóka, B., Adányi, N., Virág, D., Sabela, M. \& Kiss, A. 2012. Spoilage detection with biogenic amine biosensors, comparison of different enzyme electrodes. Electroanalysis 24(1): 181-186

Boruah, B.S., Daimari, N.K. \& Biswas, R. 2019. Functionalized silver nanoparticles as an effective medium towards trace determination of arsenic (III) in aqueous solution. Results in Physics 12: 2061-2065.

Brightwell, G. \& Clemens, R. 2012. Development and validation of a real-time PCR assay specific for Clostridium estertheticum and C. estertheticum-like psychrotolerant bacteria. Meat Science 92(4): 697-703.

Chen, X., Zhou, Y., Peng, X. \& Yoon, J. 2010. Fluorescent and colorimetric probes for detection of thiols. Chemical Society Review 391(6): 2120-2135.

Duong, H.D. \& Rhee, J.I. 2014. A ratiometric fluorescence sensor for the detection of ammonia in water. Sensors and Actuators B: Chemical 190: 768-774.

Erande, Y., Chemate, S., More, A. \& Sekar, N. 2015. PET governed fluorescence "Turn ON" BODIPY probe for selective detection of picric acid. RSC Advances 5(109): 89482-89487.

Fletcher, B., Mullane, K., Platts, P., Todd, E., Power, A., Roberts, J., Chapman, J., Cozzolino, D. \& Chandra, S. 2018. Advances in meat spoilage detection: A short focus on rapid methods and technologies. CyTA - Journal of Food 16(1): 1037-1044.

Gao, M., Li, S., Lin, Y., Geng, Y., Ling, X., Wang, L., Qin, A. \& Tang, B.Z. 2016. Fluorescent light-up detection of amine vapors based on aggregation-induced emission. ACS Sensors 1(2): 179-184.
Gribble, A. \& Brightwell, G. 2013. Spoilage characteristics of Brochothrix thermosphacta and campestris in chilled vacuum packaged lamb, and their detection and identification by real time PCR. Meat Science 94(3): 361368.

Janzen, M.C., Ponder, J.B., Bailey, D.P., Ingison, C.K. \& Suslick, K.S. 2006. Colorimetric sensor arrays for volatile organic compounds. Analytical Chemistry 78(11): 3591-3600.

Li, Y., Li, J., Lin, H., Shao, J., Cai, Z.S. \& Lin, H. 2010. A novel colorimetric receptor responding $\mathrm{AcO}^{-}$anions based on an azo derivative in DMSO and DMSO/water solution. Journal of Luminescence 130(3): 466-472.

Naila, A., Flint, S., Fletcher, G., Bremer, P. \& Meerdink, G. 2010. Control of biogenic amines in food-existing and emerging approaches. Journal of Food and Science 75(7): 139-150.

Raudienė, E., Gailius, D., Vinauskienė, R., Eisinaite, V., Balčiūnas, G., Dobilienè, J. \& Tamkutè, L. 2018. Rapid evaluation of fresh chicken meat quality by electronic nose. Czech Journal of Food Science 36(5): 420-426.

Reid, R., Burgess, C.M., McCabe, E., Fanning, S., Whyte, P., Kerry, J. \& Bolton, D. 2017. Real-time PCR methods for the detection of blown pack spoilage causing Clostridium species; C. estertheticum, C. gasigenes and C. ruminantium. Meat Science 133: 56-60.

Rodriguez-Lazaro, D., Gonzalez-García, P., Delibato,E.,DeMedici,D.García-Gimeno,R., Valero, A. Hernandez, M. 2014. Next day Salmonella spp. detection method based on real-time PCR for meat, dairy and vegetable food products. International Journal of Food Microbiology 13(8): 113-120.

Ruiz-Capillas, C. \& Herrero, A.M. 2019. Impact of biogenic amines on food quality and safety. Foods 8(62): 1-16.

Bambang Purwono* \& Beta Achromi Nurohmah

Department of Chemistry

Faculty of Mathematics and Natural Science

Universitas Gadjah Mada

Jalan Kaliurang Sekip Utara Bulaksumur 21

Yogyakarta, 55281

Indonesia

Suharman

Department of Chemistry

Universitas Sumatera Utara

Jalan T. Dr. Mansyur No. 9

Padang Bulan, Medan Baru

Medan, Sumatera Utara, 201555

Indonesia

*Corresponding author; email: purwono.bambang@ugm.ac.id

Received: 10 June 2020

Accepted: 2 September 2020 